\title{
ANÁLISIS PSICOSOCIAL DEL DISCURSO DE LA PRENSA SENSACIONALISTA PERUANA Y LAS ACTITUDES DE SUS LECTORES
}

\author{
Victor MONTERO LóPEZ ${ }^{1}$ \\ Universidad Nacional Mayor de San Marcos, Lima, Perú \\ (RECIBIDO EL 5/10/2008, ACEPTADO EL 4/12/2008)
}

\begin{abstract}
RESUMEN
Se exploró teorías explicativas de temas como la identidad, atribuciones, motivaciones, mecanismos de defensa, comunicación, representaciones sociales y actitudes; así como investigaciones sobre discursos de medios de comunicación. Se hizo acopio de ejemplares de diarios sensacionalistas para su análisis. Se pasó luego a realizar focus group con jóvenes de diversos sectores como universitarios de San Marcos, o de sectores populares como Ventanilla o escolares como del colegio José Granda. Asimismo, se realizó observaciones en diversos distritos y puntos de venta de diarios (kioscos), para luego recoger algunos testimonios. Se abordó, luego, con una encuesta a sectores representativos de jóvenes como vivienda universitaria de San Marcos en el distrito de La Victoria, Universidad Agraria de La Molina, Universidad Ruiz de Montoya, colegio José Granda en San Martín de Porres y colegio de Chorrillos, jóvenes en Ventanilla y Pamplona y pueblos jóvenes Chapi en Callao, obteniendo un universo variado con fines comparativos.
\end{abstract}

Se combinó métodos cuantitativos y cualitativos, y se realizó una encuesta con alternativas cerradas y abiertas dentro de los primeros aplicada a 511 jóvenes (255 mujeres y 256 hombres) y entre métodos cualitativos se usaron 4 focus groups, 10 observaciones en sectores poblacionales $\mathrm{B}, \mathrm{C}$ y D, 2 testimonios y 1 análisis de contenido con el total de diarios desde el 26 de enero al 3 de agosto de 2007.

Dentro de los resultados tenemos: Entender a la prensa sensacionalista como el reflejo de actitudes que se dan en nuestra población, que revelan un imaginario, representaciones sociales y atribuciones que se manejan en la cotidianidad.

El tema sexual es privilegiado en estos medios, pero no como lo pornográfico o lo erótico, sino como instrumento de consumo, intentando convertir en espectáculo lo cotidiaño y los diversos espacios sociales y discursos.

Los contenidos de esta prensa muestran violencia contra la mujer, lo cual es percibido por un muy alto porcentaje del público; sin embargo, en algunos casos, esta prensa no cuestiona esta violencia antes bien presenta supuestos causales que generaron esta violencia incluyendo el feminicidio. 
Esta prensa canaliza un tipo de comunicación prejuiciosa y a través de emociones inauténticas, lo cual revela problemas de habilidades sociales como baja autoestima y poca asertividad, y sobre todo, problemas de motivación de logro y dificultad para la toma de decisiones.

El consumo del discurso y personajes del mundo del espectáculo es alto, e incluso se da una identificación con personajes promocionados por esta prensa como vedettes y futbolistas, a través de los cuales un buen sector de la población busca realización pese a que son severamente criticados o calificados incluso, por ejemplo los futbolistas, como fracasados, y esto último está ligado a problemas de construcción de identidad nacional. Un conjunto de temores están detrás de la censura a personajes como las vedettes y charapas en un sector de la población.

Palabras clave: Identidad, actitudes, prejuicios, sensacionalismo, motivaciones, jerga.

\begin{abstract}
One explored explanatory theories of subjects like the identity, attributions, motivations, social mechanisms of defense, communication, representations and attitudes; as well as investigations on mass media speeches. Storing became of unit of daily sensationalists for its analysis. Group with young people of diverse sectors like college students of San Marcos, or popular sectors like Window or students like of the school Jose Granda soon went to make focus. Also, observations in diverse districts and points of sale of newspapers were made (kioscos), soon to gather some testimonies. It was approached soon with a survey to representative sectors of young people like university house of San Marcos in the district of the Victory, Agrarian University of the Molina, University Ruiz de Montoya, school Jose Granda in San Martin de Porres and school of Chorrillos, young people in Ventanilla and Pamplona and PPJJ Chapi in Callao, obtaining a universe varied with comparative aims.
\end{abstract}

It was combined thus quantitative and qualitative methods, as a survey with alternatives closed and opened within first applied to 511 young people ( 255 women and $256 \mathrm{men}$ ) and between qualitative methods 4 were used focus groups, 10 observations in population sectors $\mathrm{B}, \mathrm{C}$ and D, 2 testimonies and 1 analysis of content with the total of newspapers from the 26 of January to the 3 of August of 2007.

Within the results we have: To understand the press sensationalist like reflection of attitudes that they occur in our population, that reveals an imaginary one, social representations and attributions that are handled in the routine character.

The sexual subject is privileged in these means, but not like pornographic or the erótico, but as consumption instrument, trying to turn spectacle daily and the diverse social spaces and speeches.

The contents of this press show violence against the woman, which is perceived by a very high percentage of the public; nevertheless in some cases this press does not question this violence rather it presents/displays causal assumptions that they generated this violence including feminicidio.

This press canalizes a type of prejudiced communication through unreal emotions which reveals problems of social abilities like low self-esteem and little assertiveness, but mainly problems of profit motivation and decision making.

The consumption of the speech and personages of the world of the spectacle is high, and an identification with personages promoted by this press like vedettes even occurs and soccer players, as a star system through which a good sector of the population looks for accomplishment although severely they are criticized or described even considering the failed soccer players like, and this last one leagues together to problems of construction 
of national identity. A set of fears is behind the censorship to personages like vedettes and charapas in a sector of the population.

Keywords: Identity, attitudes, prejudices, sensationalism, motivations, slang.

\section{INTRODUCCIÓN}

La presente investigación psicológica es parte de una investigación más amplia de carácter interdisciplinario con profesionales de Comunicación, Literatura, Lingüística y Ciencias Sociales.

Si bien es cierto que los medios de comunicación trabajan con la complicidad del imaginario popular, el cual es construido socialmente, tal como lo muestran investigaciones de Desiderio Blanco y Julio Hevia, no se ha llegado a precisar cómo se da esto, específicamente, en nuestra realidad. Estos autores y otros, como Suárez y Rodríguez, han indicado cambios en el discurso popular que traduce cambios de actitudes, como la relevancia del cuerpo como espacio de comunicación, donde la comunicación de contacto cobra mayor importancia, a la vez que cambios en las relaciones amicales, de pareja y en general con los otros.

A través de la combinación de encuestas, entrevistas, testimonios, focus groups, observaciones y el análisis de contenido, develamos elementos no revelados en los jóvenes y cómo la prensa sensacionalista trata de canalizar impulsos, tendencias y necesidades. Esto no hubiera no hubiera sido posible con esquemas tradicionales de estudio.

\section{Diseño experimental, marco teórico}

Se exploró teorías explicativas de temas como la identidad, atribuciones, motivaciones, mecanismos de defensa, comunicación, representaciones sociales y actitudes; así como investigaciones sobre discursos de medios de comunicación incluyendo expresiones como los talk shows o reality shows, o artísticas como tecnocumbia, valses, boleros y waynos. Se hizo acopio de ejemplares de diarios sensacionalistas para su análisis; se pasó luego a realizar focus group con jóvenes de diversos sectores: universitarios de San Marcos, populares (Ventanilla) y escolares (colegio José Granda). Asimismo, se realizó observaciones en diversos distritos y puntos de venta de diarios (kioscos), para luego recoger algunos testimonios. Se abordó luego con una encuesta a sectores representativos de jóvenes como vivienda universitaria de San Marcos en el distrito de La Victoria, Universidad Agraria de La Molina, Universidad Ruiz de Montoya, colegio José Granda en San Martín de Porres y colegio de Chorrillos, jóvenes en Ventanilla y Pamplona y Pueblo Joven Chapi en Callao, obteniendo un universo variado con fines comparativos.

\section{MÉTODO}

Se combinó métodos cuantitativos y cualitativos, una encuesta con alternativas cerradas y abiertas dentro de los primeros aplicada a 511 jóvenes ( 255 mujeres y 256 hombres) y entre métodos cualitativos se usaron 4 focus groups, 10 observaciones en sectores poblacionales B, C y D, 2 testimonios y 1 análisis de contenido con el total de diarios desde el 26 de enero al 3 de agosto de 2007. 


\section{RESULTADOS}

\section{Mensajes en los diarios sensacionalistas}

La presentación de titulares discriminatorios o de contenido sexual de parte de los diarios sensacionalistas provoca en sus lectores comentarios cargados de agresividad y un lenguaje coprolálico.

El discurso de los participantes en el focus indica que las nociones e imágenes asociadas a la nación, racismo y género están muy distorsionadas en la prensa sensacionalista; pero, además, en ellos mismos hay gran confusión y distorsión, teniendo una imagen y un imaginario muy limitados.

Es así que lo educativo es restringido a los materiales escolares, obvian el tratamiento de los grandes problemas nacionales o de las alternativas, o de los análisis de aspectos trascendentes. El país es conceptuado a partir de lo que pudieran pensar los extranjeros sobre sus habitantes, con preocupación por la presencia de la delincuencia que pueda dar lugar a generalizaciones injustas que a ellos los descalifiquen. Posiblemente, sienten que ello acentuaría su condición de limitación económica y marginalidad.

En la noción de género, les preocupa, sobre todo, la imagen de la mujer como sujeto asociado a las imágenes de las vedettes, que son a su vez objeto de escándalo; lo otro asociado a la mujer sería la prostitución; sin embargo, ellos mismos parecen sugerir que hay algo de envidia social por el éxito de las vedettes, lo que les crea un conflicto pues, por un lado, son desvalorizadas y escandalizadas, pero por otro tienen ascenso social y reconocimiento de su atractivo físico.

Son posibles muchos mecanismos de represión, racionalización, proyección, sublimación, condensación. Es así muchas experiencias negativas no se expresan y se reprimen. Inventan explicaciones aceptables para justificar actos como la ambivalencia que le pueden crear estos diarios.

La actitud ante estos diarios y los medios en general es bastante crítica, evidenciando que los jóvenes, especialmente del sector pobre de la población, no son meros sujetos pasivos o acríticos frente a los mensajes que reciben y demandan calidad, democracia y participación. Incluso logran discriminar niveles de persuasión en las imágenes precisando cuándo es un desnudo y cuándo éste tiene una intencionalidad.

Su cotidianidad está llena de estereotipos y prejuicios raciales y económicos, que no los libra de la discriminación entre ellos. Es así que a veces, los artistas y personajes de los medios sensacionalistas se constituyen en sujetos que proyectan y censuran. La valoración está dada incluso por discriminar lo indígena pese a tener diversos rasgos indígenas. Dentro de ello, estos medios sensacionalistas son una vitrina donde obtener valoraciones, censuras, descalificaciones, críticas y autorrechazo.

Los datos que obtienen de los diarios y de los medios en general a veces son distorsionados, confusos y los reafirman en una percepción negativa de la clase política.

Es posible que la censura a la jerga empleada, tenga que ver con su necesidad de no ser excluidos, de no ser considerados vulgares o de ser menos valorados. 
Hay señalamiento de escasa credibilidad de estos diarios sensacionalistas, así como fuerte rechazo y censura por los escándalos, por el hurgar en la vida privada, por el chisme, por lo negativo de la farándula; pero paralelamente hay una fuerte pulsión de ver, de tener alguien a quién criticar; aunque el sujeto censurante les da la idea de pretensión de perfección, lo que les crea conflicto.

Es posible que ellos vivan su propia forma de asumir una nación, porque lo oficial no responde a sus intereses, ni hay alternativas que los incluyan.

Estos diarios en general son definidos como sensacionalistas, con otras palabras al resaltar la exageración y el buscar atraer como sea la atención del público los denominan "diarios chicha", lo que implica una clara diferenciación de otros diarios.

No encontramos ninguna crítica al feminicidio constante; al contrario en los diversos crímenes a las mujeres se las hace aparecer con el rótulo de "calentona", "golosa"; a veces bajo el camuflaje de "denuncia" asocia siempre el sexo a la violencia ("Estrangula amante por cucú de jerma", "Poli loco revienta a tombita por celos", "Pastor diablo viola a chiquilla") o las relaciones familiares con poca tolerancia y poco control emocional ("Mamita golpea y bota a bebe al basural", "Mamá mata hijo y se envenena", "Abuela maldita mató a nietecita", "Le clavan 30 puñaladas contra la pared”).

Se le asocia a la mujer a una constante demanda de tener sexo "bravo" que sugiere muchas veces violencia, presentando imágenes de "tías calentonas", "charapas", "gordas golosas", "tías chiboleras", "gringas", "solteronas", "debutantes", "borrachas", "divorciadas", "pechugonas". Los hombres son presentados como necesitados de servicios para mejorar su actuación sexual y superar problemas: "Como moverle la lengua a tu hembra", "Seis juguetes para gozar rico", "Huevo de toro te da vigor sexual", "Jugo contra eyaculación precoz", "Veneno de araña cura impotencia", "Kion aumenta vigor sexual", "5 plantas para durar más", "Rico chuculún según tu signo", "Cerveza cura la impotencia", "Dura 6 horas con leche de burra", "Dura 6 horas con hígado de conejo", etc.

A su vez la población aparece como teniendo un libertinaje que inunda todos los espacios: "Hacen chuculún en plena calle", "Las filman borrachas sin calzón", "Graban natachas calatitas", "Borrachas se calatean en polladas", "Filman calzones en combis", "Filman a guachis en chuculum", "Filman a vecinos gozando en jardín", "Filman orgías en viajes turísticos", etc.

Se presenta a la vez, la idea de numerosas personas en búsqueda de encuentros sexuales: "Solteronas buscan machos sin chamba", "Parejas dan 200 soles por sexo bravazo", "Charapas de 40 buscan sexo grupal", "Debutantes cobran 100 soles por película", "Dan chuculún en baño de cantinas", "Pide sexo a forro", "Charapas dan cucú paraditas", "Casadas aburridas piden machos de 20". Incluso las noticias de diversos géneros periodísticos son asociados a lo sexual, así referido al deporte señalan por ejemplo: "Perú se metió 3 al hilo".

Sin embargo, estos contenidos disminuyeron para enfatizar el "dolor" frente a los accidentes sufridos por el grupo "Néctar" o de "La princesita Sally", esto asociado igualmente a generar identificación, pues tanto en lo sexual a través de las vedettes o los artistas se ofrece una supuesta realización, es decir a través del sistema de estrellas se promueve 
una identificación y seguimiento a cada paso cotidiaño de los artistas de la farándula, dando a saber con quién está saliendo, quién le hizo un regalo, a quién dejó por ella, a qué "triunfador" por lo general futbolista desean ("Potoncitas quieren con El Chemo", "Claudia le da pechazos al Chemo", "Malú se moja por Alan”, "Copa de colitas calientes", "Chalacas bajan calzón por peloteros" etc.).

Por su parte, Ajá supuestamente presenta las noticias de actualidad como lo central, pero siempre asociado a temas de farándula que son competitivos. Las noticias ofrecen casi siempre una actitud pesimista ante la vida y las personas, mostrando violencia ("Masacra hijito, "Papá bestia le fracturó cabecita y costillas"). Mientras que las noticias diarias de la farándula, hacen alusión a opiniones de una vedette o cómico sobre otras vedettes, se enfatiza en los insultos, "ampays", peleas, burlas, etc. No se trata de mostrar emociones que son auténticas y normales que aparezcan por ser básicas y comprensibles, sino que se enfatiza en falsas emociones o emociones inauténticas asociadas a trastornos clínicos como son: el resentimiento en vez de cólera, la envidia y el triunfo maligno (alegrarse del mal ajeno) en vez de tristeza o cólera, la depresión (que lleva hasta el suicidio) y melancolía en vez de tristeza, triunfalismo en vez de alegría, descontrol emocional y obsesión en vez de placer o afecto. No solo ello, sino que están asociados a programas narrativos de desposesión o apropiación de afectos, propiedades, etc., y la atribución aparece para asignar una cualidad descalificativa al rival. Primando impulsores emocionales como "trata más" (insistir sin concluir proyectos, ni relaciones, etc.), y "se fuerte" (fingir no sentir ninguna emoción ni haberle afectado), los fracasos se asocian al programa "complace" (meterse en líos por complacer a los demás), no se menciona casi el "es perfecto" (pero se descalifica a los demás, irrogándose autoridad para juzgar y sentenciar, así como calificar).

La identificación con "las estrellas" es mucho más acentuada en Ajá haciendo de la cotidianeidad un espectáculo ("Melissa cambia a Foquita por empresario", "Marina se separa de primo esposo", "Susy se queda sorda", July se amarra con billarista, "Paola no suelta a garoto", "Angie calatita conquistó público", "Urraca busca mariachi”, "Jackie hace cachita a Tula", "Tula tira arroz a Chiquito", "Katty Rojas jura no chapó con Mañolo", "Chapetón puso al día a Mercedes"). Esto se asocia a una fuerte promoción de estos personajes de la farándula: "Rubí misma Bolocco", "Danuska inicia guerra de cucús", "Gladis (Trocones) moverá curvas con Alvarez", "Zanetti se luce misma Bolocca", "Diablitas elevan la temperatura", "Miski Tayki mamacita", "Amiga de todos (Francis) mostró chichis", Daysi cobra 150 dólares", “Acusan de prosti a Viviana”, "Cristina quiere ser vedette", "Francis con doble pechuga", etc.)

Igual que El Chino, Ajá puso énfasis tanto a lo sucedido con Néctar como con "La princesita Sally", e igual cuando ganó la selección de futbol peruana ("Machazos. Después de 25 años vamos a un Mundial”). Igualmente contrastante pero tratando de continuar esta lógica se da en Semana Santa ("Dios mío, río se desborda arrasa viviendas en Jauja. Susy (Díaz) se vuelve santa”).

En este diario, las noticias relacionadas a la coyuntura en raros casos critican al gobierno de Fujimori y en todo momento apuntan a afirmar una buena imagen del gobierno de Alan García ("Alan galopa en aprobación popular", "Chamba para universitarios cráneos", “Alva Castro jura acabará con narcos", "No se asusten con alza de combustibles”, etc.); 
la oposición es criticada constantemente, pero con la suficiente habilidad como para mantener a la vez una imagen popular ("Todo el Sur alista protestas", "Profes bravos con gobierno", etc.)

El Trome busca ser aceptado por la población, brinda una imagen de mayor seriedad por encima de El Popular, Ajá y El Chino. Trome enfatizó mucho en el tema de la selección peruana pero siempre magnificándola (“Te amo Perú, selección 17 empató 1-1 con Argentina y clasificó”, "Juego sucio, arbitro nos robó penal con Venezuela”. Estas noticias también van asociadas a la farándula ("Paola: amo a Danilo y qué"); igualmente tuvo una amplia cobertura de la infidelidad de Cecilia Bolocco (“Ampay Bolocco”).

El Popular igualmente trata de mostrarse objetivo y hasta crítico, pero asocia la coyuntura a la farándula, dio también amplia cobertura al tema Bolocco, y promociona a los personajes de la farándula ("Nadie tiene un par como yo. Francis muestra delantera", "Shirley: Así no me crean soy virgen”). Dio gran promoción al tema selección peruana magnificándola ("Allá vamos Mundial"), asoció noticias faranduleras ("Chicas en guerra de banderas, rotita se pinta bandera peruana en su cuerpo", "Maribel: Tula me quitó a Chiquito")

En general, todo este universo, donde lo sexual está magnificado, tiene un fin consumista evidente, pues los avisos de servicios sexuales diversos aumentan, paralelamente a servicios de curanderismo y prácticas abortivas.

Diarios, como el Ojo y el Extra, no dejan de ser sensacionalistas, pero en menor medida; sin embargo presentan titulares como: "Se viene la III Guerra Mundial", Peligro de guerra con Chile". Igualmente se asocia la coyuntura con temas de la farándula ("Francis enseña teteras"). Ambos diarios trataron el tema Bolocco ("Ampay Bolocco").

Este análisis nos permitió visualizar que hay diferencias entre los titulares de los diarios El Chino y Ajá tienen diferentes lógicas, pues se podría pensar que ambos tendrían numerosos titulares con temas sexuales pero esto solo se da en El Chino donde esto es muy significativo, a tal punto que el tema se subdivide en diversos tópicos, razón por la cual se los ordenó según esa lógica: sucesos que se presentaban como curiosidades sexuales para comunicarlas al público, las referidas a la farándula (donde se destacaba determinadas cualidades sexuales de las vedettes), las amenidades sexuales (que incluía horóscopos, calendarios y chistes sexuales), los delitos que incluían asesinatos y feminicidio s (que eran casi en su totalidad asesinatos a mujeres y otras que eran delitos sexuales como violaciones), recetas y consejos sexuales (donde presentan plantas para mejorar el desempeño sexual, técnicas coitales para aumentar el placer, etc.) e historietas de aventuras sexuales o fotonovelas (básicamente relacionadas con personajes especie de "superhéroes".

Respecto al diario El Chino los titulares sexuales son los más frecuentes y llegan al $67,3 \%$ dividiéndose de la siguiente manera: los sucesos o "curiosidades" con 22,5\%, las referidas a la farándula con $4,5 \%$, las amenidades sexuales con 7,6\%, los delitos, asesinatos y feminicidio s con $8,4 \%$, recetas y consejos sexuales con $19,4 \%$ e historietas de aventuras sexuales o fotonovelas con 5,3\%. Luego, le siguen los titulares policiales con $13,3 \%$ y los de espectáculo con $10,7 \%$, siendo los nacionales y los deportivos los menos presentados con $6,5 \%$ y $1,5 \%$ respectivamente. Esto prácticamente presenta una imagen del diario como de contenido sexual, se podría pensar que trataría de destacar lo deportivo 
en titulares que impacten pero ello no se da, más bien relaciona sus contenidos sexuales con lo deportivo en términos de seducción de determinados personajes de la farándula (diversas vedettes) hacia los deportistas, especialmente futbolistas de la selección nacional o de los clubes más preferidos. Tampoco se da abundantes titulares sobre las vedettes o artistas, solo llega al 10,7\%.

El diario Ajá es un diario que promociona claramente a los artistas de la farándula y especialmente a las vedettes (con un grupo muy nutrido que espera su turno para ser promocionado), evidentemente resalta el enfrentamiento entre las vedettes tratando de que se respondan entre ellas a las acusaciones o insultos que se intercambien. Es por ello, que los titulares del espectáculo llegan al 65,4\% y en segundo lugar están las noticias nacionales, comprendiendo lo económico, político, desastres nacionales, no encontrándose como en el caso de El Chino curiosidades como apariciones religiosas (vírgenes que lloran), datos laborales, apariciones o fenómenos extraños (fantasmas u otros), en el caso de Ajá estas noticias nacionales llegan al 26,7\%, pero con un sentido sensacionalista, para nada son titulares ni descriptivos o explicativos, tampoco orientadores en sentido positivo sino de generar expectativa sobre hechos que nos pueden impactar. Con mucho menor porcentaje están las noticias policiales con 5,9\% y las deportivas con 1,4\%, en el caso de sexual solo apareció en una ocasión un titular referido al gusto sexual de los peruaños. Las noticias deportivas si aparecen están relacionadas con el espectáculo e igual sucede con las policiales.

Se encuentra que El Chino arma, en base a las noticias de actualidad, historias fantasiosas. No encontramos ninguna crítica al feminicidio y la mujer está asociada a una constante demanda sexual. A su vez, la población aparece como libertina e inunda todos los espacios. Se presenta a la vez, la idea de numerosas personas en búsqueda de encuentros sexuales. Tanto en lo sexual a través de las vedettes o los artistas se ofrece una supuesta realización, es decir a través del sistema de estrellas se promueve una identificación y seguimiento a cada paso cotidiaño de los artistas de la farándula.

Si comparamos ambos diarios encontramos cómo El Chino privilegia lo sexual con todo detallamiento para canalizar el interés por este tema, en cambio Ajá privilegia el espectáculo subordinando lo sexual a éste para promocionarlo; en el caso de la presencia de noticias deportivas, en ambos casos se da en baja proporción subordinándolas a su principal interés, e igualmente sucede con las policiales donde interesa como fondo para mantener la atención y presencia del público consumidor, la noticia es más bien manipulada para el fin central. Respecto a las nacionales, El Chino no muestra mayor interés en su tratamiento a no ser que lo use para un fin específico, en cambio Ajá si trata de tenerlo presente, contrastan sus porcentajes de $6.5 \%$ frente al $26.9 \%$, pero en estos titulares no hay tampoco objetivos descriptivos o explicativos, tampoco buscan orientar positivamente, sino mantener la lógica sensacionalista, que es justamente lo que permite manipular la evasión, desesperanza y falsa realización en el público ya cautivo o introducir esta lógica en los potenciales consumidores.

En general, todo este universo, donde lo sexual está magnificado, tiene un fin consumista evidente, pues los avisos de servicios sexuales diversos aumentan, paralelamente a servicios de curanderismo y prácticas abortivas. 
En síntesis, esta prensa sensacionalista vende evasión, desesperanza y falsa realización. Lejos de ofrecer objetividad para analizar la realidad, se ofrece evasión, formas prejuiciosas y estereotipadas de ver la realidad. La visión de lo humaño, de las relaciones, del país, de los personajes, de las personas es sumamente pesimista. Se ofrece compensar la pobreza de habilidades sociales, la incomunicación, la baja autoestima existente en la población peruana con una falsa realización a través del seguimiento de la cotidianeidad de los personajes de la farándula. Igualmente, la pornografía no está asociada a lo sexual, pues lo que hay es un tratamiento de lo erótico en el sentido de consumo de imágenes y formación de un imaginario sobre los personajes de la farándula, tratando de "vedettizar" incluso a los personajes políticos, intelectuales, etc., y erotizar los diversos espacios públicos y privados, así lo pornográfico se extiende a la presentación morbosa de los accidentes, crímenes, maltratos, líos amorosos asociados a simbiosis destructivas, todo ello facilita la instalación de diversas guerras psicológicas disponibles en estos medios según el caso (de un individuo contra otro individuo, de un individuo como Montesinos contra un grupo, de un grupo contra otro grupo, de un grupo contra un individuo). Toma sentido aquí el equívoco del discurso presidencial que en vez de decir: "vamos a alfabetizar" dijo: "vamos a analfabetizar", pues evidente que esta prensa promueve un tipo de analfabetismo en el tratamiento y análisis los de problemas.

Tabla N. ${ }^{\circ}$ 1. Comparación de tipos de titulares en El chino y Ajá.

\begin{tabular}{|c|c|c|c|c|c|c|}
\hline \multirow{2}{*}{ Tipos de noticias } & \multicolumn{2}{|c|}{ El chino } & \multicolumn{2}{|c|}{ Ajá } & \multirow{2}{*}{$\begin{array}{c}\text { Total } \\
\text { frecuencia }\end{array}$} & \multirow{2}{*}{$\begin{array}{c}\text { Total } \\
\%\end{array}$} \\
\hline & Frecuencia & $\begin{array}{c}\% \mathrm{de} \\
\text { aparición }\end{array}$ & Frecuencia & $\begin{array}{c}\% \mathrm{de} \\
\text { aparición }\end{array}$ & & \\
\hline Sexuales & 178 & 67,3 & 1 & 0,3 & 178 & 32,5 \\
\hline Espectáculos & 28 & 10,7 & 187 & $65, .4$ & 215 & 39,2 \\
\hline Policiales & 35 & 13,3 & 17 & 5,9 & 52 & 9,5 \\
\hline Deportivas & 4 & 1,5 & 4 & 1,4 & 8 & 1,4 \\
\hline $\begin{array}{l}\text { Nacionales (politica, } \\
\text { economía, curiosidades) }\end{array}$ & 17 & 6,5 & 77 & 26,9 & 94 & 17,1 \\
\hline Total por diario & 262 & 100,0 & 286 & & 548 & 100,0 \\
\hline
\end{tabular}

Hay diferencias entre los titulares de los diarios El chino y Ajá, es así que tienen diferentes lógicas, pues se podría pensar que ambos tendrían numerosos titulares con temas sexuales pero esto solo se da en El chino donde esto es muy significativo, a tal punto que el tema se subdivide en diversos tópicos: sucesos que se presentaban como curiosidades sexuales para comunicarlas al público, las referidas a la farándula (donde se destacaba determinadas cualidades sexuales de las vedettes), las amenidades sexuales (que incluía horóscopos, calendarios y chistes sexuales), los delitos que incluían a asesinatos y feminicidio s (que eran casi en su totalidad asesinatos a mujeres y otras que eran delitos sexuales como violaciones), recetas y consejos sexuales (donde presentan plantas para mejor desempeño sexual, técnicas coitales para aumentar el placer, etc.) e historietas de aventuras sexuales o fotonovelas (básicamente relacionados con personajes especie de "superhéroes". 
Si comparamos ambos diarios encontramos cómo El chino privilegia lo sexual con todo detalle para canalizar el interés por este tema, en cambio Ajá privilegio el espectáculo subordinando lo sexual a este para promocionarlo, en caso de la presencia de noticias deportivas en ambos casos se da en baja proporción subordinándolas a su principal interés, e igualmente sucede con las policiales donde interesa como fondo para mantener la atención y presencia del público consumidor, la noticia es más bien manipulada para el fin central. Respecto a las nacionales, El chino no muestra mayor interés en su tratamiento a no ser que lo use para un fin específico, en cambio Ajá si trata de tenerlo presente, contrastan sus porcentajes de $6.5 \%$ frente al $26.9 \%$, pero en estos titulares no hay tampoco objetivos descriptivos o explicativos, tampoco buscan orientar positivamente, sino mantener la lógica sensacionalista.

\section{Preferencias y calificativos sobre la prensa sensacionalista}

Veamos los resultados sobre preferencias y calificativos obtenidos en la población estudiada.

Tabla N. ${ }^{\circ}$ 2. Percepción de preferencia de diarios por la población estudiada.

\begin{tabular}{lccc}
\hline \multicolumn{1}{c}{ Diario } & Femenino & Masculino & $\mathbf{X}$ \\
\hline Trome & 40.7 & 40.13 & 40.4 \\
Correo & 15.7 & 13.2 & 14.4 \\
Ajá & 5.2 & 11.1 & 8.1 \\
El Chino & 6.6 & 8.1 & 7.3 \\
El Popular & 17.4 & 11.1 & 14.2 \\
Ojo & 11.1 & 9.8 & 10.4 \\
Extra & 3.5 & 0.5 & 2.0 \\
Perú 21 & 8.7 & 14.5 & 11.6 \\
No responde & & 0.6 & 0.3 \\
TOTAL & 100.0 & 100.0 & 100.0 \\
\hline
\end{tabular}

Al ser encuestados los jóvenes señalan al Trome como el diario que sería el preferido, y luego a Correo, El Popular, Ojo y Ajá en ese orden. Trome es percibido como preferido mayormente por los varones, Correo por las mujeres, los otros diarios son percibidos como preferidos por los varones a excepción de El chino y El popular que es percibido como preferido mayormente por las mujeres. Indican leer más al Trome y luego Correo, El popular y Ojo. 
Tabla N. ${ }^{\circ}$ 3. Preferencia de lectura en la población estudiada.

\begin{tabular}{lccc}
\hline \multicolumn{1}{c}{ Diario } & Femenino & Masculino & $\mathbf{X}$ \\
\hline Trome & 24,4 & 33,0 & 28,7 \\
Correo & 20,2 & 19,5 & 19,8 \\
Ajá & 5,3 & 5,5 & 5,4 \\
El chino & 4,0 & 0,8 & 2,4 \\
El popular & 17,8 & 11,3 & 14,5 \\
Ojo & 9,5 & 13,3 & 11,4 \\
Extra & 2,8 & 3,7 & 3,2 \\
Perú 21 & 2,0 & 2,8 & 2,4 \\
La razón & - & 0,9 & 0,4 \\
Líbero & & 1,8 & 0,9 \\
No responde & & 1,1 & 0,6 \\
TOTAL & 100,0 & 100,0 & 100,0 \\
\hline
\end{tabular}

La preferencia de lectura según sexo coincide con la percepción de preferencia, así los varones leen en mayor porcentaje que las mujeres los diversos diarios, a excepción de Correo, El chino y El popular que son leídos mayormente por las mujeres. Llama la atención que los lectores de El chino sean mayormente mujeres y que el consumo de Ajá sea casi igual entre ambos sexos; sin embargo, vemos notoria diferencia en la lectura de Trome a favor de los varones; y si sumamos los porcentajes veremos que los diarios que son considerados más sensacionalistas (dentro de lo cual se ubican Trome, El popular, Ajá y El chino) e igual sucede si sumamos los porcentajes del conjunto de diarios, veremos que estos son más leídos por los varones.

Tabla N. ${ }^{0}$ 4. Frecuencia de lectura en la población estudiada.

\begin{tabular}{lccc}
\hline \multicolumn{1}{c}{ Frecuencia } & Femenino & Masculino & $\mathbf{X}$ \\
\hline Una vez a la semana & 40,7 & 30,7 & 35,7 \\
2 veces a la semana & 22,9 & 23,0 & 22,9 \\
Todos los días & 15,1 & 22,8 & 18,9 \\
Otro a veces & 16,0 & 13,1 & 14,5 \\
No responden & 5,8 & 0,5 & 3,1 \\
TOTAL & 100,0 & 100,0 & 100,0 \\
\hline
\end{tabular}

Respecto a la frecuencia con que leen diarios, vemos que la población masculina presenta mayor frecuencia llegando un $22.8 \%$ de varones a leer todos los días. Analizando los sectores vamos a ver que entre los varones se lee más frecuentemente en Callao y 
Chorrillos y con menor frecuencia en la Agraria y la Vivienda. Entre las mujeres se lee más frecuente igualmente en Chorrillos y luego en Ventanilla y con menor frecuencia en la Ruiz y la Agraria.

Sobre el lugar donde leen diarios el $85.3 \%$ de mujeres y un $56.7 \%$ de varones lee en su casa; la lectura en el medio de transporte (combi) y en el centro de estudios es mayor entre los varones, e igual en el kiosco donde llega a un $25.3 \%$ frente a un pequeño $6.5 \%$ de mujeres. Al interior de los sectores poblacionales donde más se lee en la combi es en Vivienda y Ventanilla, donde más leen en el kiosco es en Vivienda y la Ruiz. Los que más leen en su casa son en el Callao y el Granda, esto en relación a los varones. En el caso de las mujeres, donde más se lee en la combi es en Pamplona aunque con bajos porcentajes, donde más leen en el kiosco es en Pamplona. Los que más leen en su casa son en el Callao y Chorrillos.

Tabla N. ${ }^{\circ}$ 5. Preferencia de secciones en diario en la población estudiada.

\begin{tabular}{lccc}
\hline \multicolumn{1}{c}{ Secciones preferidas } & Femenino & Masculino & $\mathbf{X}$ \\
\hline Política & 21,0 & 21,1 & 21,0 \\
Deportes & 6,8 & 44,6 & 25,7 \\
Policial & 21,8 & 11,6 & 16,7 \\
Espectáculo & 45,0 & 23,7 & 34,3 \\
Otra chistes, amenidades & 6,3 & 5,0 & 5,6 \\
Economía,cultural & 5,8 & 4,5 & 5,1 \\
TOTAL & 100,0 & 100,0 & 100,0 \\
\hline
\end{tabular}

Sobre la preferencia a las secciones que leen, los varones presentan mayor frecuencia en las secciones deportes donde llega a un $44,6 \%$ frente a un 6,8\% en las mujeres; mientras que las mujeres tienen mayor preferencia que los varones en las demás secciones a excepción de la política donde ambos llegan al $21 \%$. En general, en la población, las noticias del espectáculo son las más leídas pero es mayor en las mujeres donde llega al $45 \%$ frente a un $23,7 \%$ de varones; mientras que la sección policial se ubica en un cuarto lugar luego de la deportiva, política y espectáculos; aunque hay un 5,6\% de personas que busca amenidades o chistes.

Señalan que las personas que más leen estos diarios son los adultos: 46,4 y luego los jóvenes $27,8 \%$, siendo mayor el porcentaje de mujeres que considera lo leen los adultos $(63,4 \%)$. Y la opinión sobre si de los jóvenes y adolescentes quiénes son los que más leen estos diarios, piensan lo hacen son los trabajadores $(32,5 \%)$, Desempleados $(30,7 \%)$ y Estudiantes $(28,9 \%)$

Respecto a noticias de la TV aparecen más en estos diarios, señalan mayormente a las de Espectáculos $49,8 \%$ y luego las Policiales $18,8 \%$, siendo las mujeres las que más mencionan las policiales con $24,5 \%$ y los varones las de espectáculos con $53 \%$, mientras que las noticias políticas y deportivas tienen similares porcentajes, mayormente entre los varones. 
En la población en general le dan mayor credibilidad a las noticias del espectáculo (credibilidad alta en $25,6 \%$ ) y politicas (con credibilidad alta de 16\%). Aunque si sumamos la credibilidad alta y media, las policiales tienen $68.4 \%$ mientras que las políticas tienen $64 \%$ y las de espectáculos $61,6 \%$. Son principalmente mujeres las que tienen credibilidad alta frente a las noticias políticas y de espectáculos, igual que credibilidad media frente a las policiales y de espectáculos; pero los varones tienen credibilidad alta frente a las policiales y media frente a las políticas. Estando la credibilidad más baja frente a las de espectáculos y policiales; siendo mujeres en su mayoría las que señalan no le dan ninguna credibilidad a ninguna de estas tres noticias. Estos datos contrastan con su porcentaje de lectura en el caso de espectáculos.

La mayor valoración la dan a Trome, Correo y Perú 21, pero, sin embargo, este último es poco leído por ellos. Mientras que los peor calificados son Ajá (incluso alto porcentaje lo tipifica como malo) y El chino (con alto porcentaje que lo denomina "basura").

Tabla N. ${ }^{\circ}$ 6. Porcentajes en tèrminos para calificar al diario Trome, según sexo en la población estudiada.

\begin{tabular}{lccc}
\hline \multicolumn{1}{c}{ Términos para calificar al diario trome } & Femenino & Masculino & Total \\
\hline Regular & 18,4 & 17,4 & 17,9 \\
Chicha & 1,3 & 2,5 & 1,9 \\
Malo, pobre & 3,1 & 6,3 & 4,7 \\
Bueno, serio & 26,8 & 17,7 & 22,2 \\
Bajo nivel & 0,7 & 1,9 & 1,3 \\
Farandulero & 1,5 & 3,0 & 2,2 \\
Sensacionalista & 0,7 & 4,2 & 2,4 \\
Vulgar & 1,3 & & 0,6 \\
No sabe & 21,8 & & 10,9 \\
$\begin{array}{l}\text { Poco serio } \\
\text { Otros: denigrantes, elegante, incoherencia, poco verídico, } \\
\text { morboso, regular, creíble, ordinario, aceptable, popular, ex- } \\
\text { celente, divertido, pésimo, mañoso, informativo, no político, } \\
\text { medio, dudable, mediocre, pasable, tabloide, interesante, } \\
\text { basura, espectáculo (c/u) }\end{array}$ & 0,3 & & 0,1 \\
\hline
\end{tabular}

Trome es considerado por la mayoría como bueno y serio $(22,2 \%)$ considerado así mayormente por las mujeres $(26,8)$, luego otros lo consideran regular bordeando el $18 \%$; y en mucho menor porcentaje lo califican como malo, pobre, de bajo nivel, farandulero, chicha, sensacionalista, y vulgar, siendo calificado así sobre todo por los varones. Aunque un menor porcentaje de personas (con ligero predominio de los varones) lo califican con otros adjetivos negativos. Entre los sectores poblacionales masculinos vemos que Trome obtiene mejores calificativos en Ventanilla y Callao y los calificativos más negativos en la Ruiz. Entre los sectores poblacionales femeninos vemos que Trome obtiene mejores calificativos en Chorrillos y Pamplona y los calificativos más negativos en el Granda. 
Cuadro N. ${ }^{0}$ 7. Porcentajes en términos para calificar al diario Correo, según sexo en la población estudiada.

\begin{tabular}{llccc}
\hline \multicolumn{1}{c}{ Términos para calificar al diario } & \multicolumn{2}{c}{ Sexo } \\
& Femenino & Masculino & Total \\
\hline Regular & 15,6 & 16,8 & 16,2 \\
Bueno & 23,6 & 17,2 & 20,4 \\
Malo & & 4,5 & 2,2 \\
& Politiquero & 3,0 & 7,5 & 5,2 \\
Correo & Informativo & 4,3 & 9,9 & 7,1 \\
& Aburrido & 0,9 & 1,0 & 0,5 \\
& Vulgar & 0,8 & & 0,4 \\
& Farandulero & 1,7 & & 0,8 \\
Otros: importante, prostitución, lo mejor sensaciona- & 5,8 & 5,8 & 5,8 \\
& lista, serio, educativo, entretenido, interesante, c/u & & & \\
\hline
\end{tabular}

Respecto a Correo, la mayoría lo califica bueno $(20,4 \%)$ y otros regular; y la minoría dice que es informativo y malo, y tiene rechazo de algunos por ser "politiquero". Son las mujeres las que lo califican mejor. Entre los sectores poblacionales masculinos, los calificativos más positivos los obtuvo en Chorrillos y Callao y los más negativos en la Vivienda. Entre los sectores poblacionales femeninos, vemos que obtiene mejores calificativos en Pamplona y los calificativos más negativos en la Ruiz.

Tabla N. ${ }^{\circ}$. Porcentajes en términos para calificar al diario Ajá, según sexo en la población estudiada.

\begin{tabular}{lccc}
\hline \multicolumn{1}{c}{ Términos para calificar al diario } & \multicolumn{3}{c}{ Sexo } \\
& Femenino & Masculino & Total \\
\hline Chicha & 7,9 & 3,3 & 5,6 \\
Vulgar & 7,3 & 7,0 & 7,1 \\
Malo, desagradable & 15,6 & 17,6 & 16,6 \\
Basura, porquería, & 3,8 & 5,6 & 4,7 \\
Bueno & 1,4 & 3,8 & 2,6 \\
No leo, no sé & 20,6 & 15,6 & 18,1 \\
Popular & - & 3,5 & 1,7 \\
Farandulero & 0,9 & 5,0 & 2,9 \\
Desastre & 1,9 & 1,8 & 1,8 \\
Porno & 3,5 & & 1,7 \\
Regular & 12,3 & & 6,1 \\
$\begin{array}{l}\text { Otros: denigrante, barato, asco, imprudente, cómico, pacharaco, } \\
\text { obsceno, sucio, ordinario, controversial, entretenido, regular, } \\
\text { chevere, malintencionado, mentiroso, grosero, divertido, engañoso, } \\
\text { amarillo, negativo }\end{array}$ & 5,1 & & \\
\hline
\end{tabular}


Sobre $A j a ́$, la mayoría lo califica negativamente, así es más denominado como malo y desagradable $(16,6 \%)$, a la vez que un $18 \%$ dice no leerlo y no saber. Siendo los hombres los que dieron mayores calificativos negativos, a excepción de porno y vulgar que es más mencionado por las mujeres. Entre los sectores poblacionales masculinos los calificativos más positivos lo obtuvo en Chorrillos y los más negativos en la Vivienda y la Ruiz, es de mencionar que en todos los sectores se mencionó es vulgar. Entre los sectores poblacionales femeninos vemos que obtiene mejores calificativos en Pamplona y los calificativos más negativos en Callao y la Ruiz.

Tabla N. ${ }^{\circ}$ 9. Porcentajes en términos para calificar al diario El chino según sexo en la población estudiada.

\begin{tabular}{lccc}
\hline Términos para calificar al diario & \multicolumn{3}{c}{ Sexo } \\
& Femenino & Masculino & Total \\
\hline Regular & 7,2 & 3,8 & 5,5 \\
Bajo nivel & 2,8 & 2,5 & 2,6 \\
Basura & 3,7 & 12,2 & 7,9 \\
Pésimo & 10,1 & 4,8 & 7,4 \\
Mentiroso & 7,0 & 1,0 & 4,0 \\
Vulgar, porquería & & 6,5 & 3,2 \\
Chicha & 8,7 & 6,9 & 7,8 \\
Malo & 12,6 & & 6,3 \\
No sé & 11,3 & & 5,6 \\
Farandulero & 1,6 & & 0,8 \\
Porno & 7,1 & & 3,6 \\
Otros: sensacionalista, porno, locazo, & & & \\
bueno, prostitución, morboso, absur- & & & \\
do, informativo, divertido, tontería, & 5,6 & 6,9 & 6,2 \\
mentiroso, exagerado, controvertido, & & & \\
horrible, divertido, grosero amarillo, & & & \\
poca información & & & \\
&
\end{tabular}

Con respecto a El chino, los calificativos negativos son los más mencionados, sobre todo: basura, chicha, pésimo, mentiroso, porno y de bajo nivel Entre los sectores poblacionales masculinos los calificativos más positivos pero que lindan dentro de lo regular lo obtuvo en la Vivienda y los más negativos en Chorrillos y Ventanilla Entre los sectores poblacionales femeninos, vemos que obtiene mejores calificativos pero dentro de lo "regular" en Pamplona y minoritariamente en el Granada, y los calificativos más negativos en Ventanilla. 
Tabla N. ${ }^{\circ}$ 10. Porcentajes en términos para calificar al diario El popular según sexo en la población estudiada.

\begin{tabular}{|c|c|c|c|c|}
\hline \multirow{2}{*}{\multicolumn{2}{|c|}{ Términos para calificar al diario }} & \multicolumn{3}{|c|}{ Sexo } \\
\hline & & Femenino & Masculino & Total \\
\hline \multirow{10}{*}{ El popular } & Chicha & 12,2 & 7,5 & 9,8 \\
\hline & Basura & & 12,0 & 6,0 \\
\hline & No leo & 13,2 & 20,1 & 16,6 \\
\hline & Informativo & & 5,1 & 2,6 \\
\hline & Sensacionalista & 5,2 & 2,9 & 4,0 \\
\hline & Farandulero & 2,6 & 2,2 & 2,4 \\
\hline & Bueno & 14,7 & 11,7 & 13,2 \\
\hline & Malo & 5,9 & & 3,0 \\
\hline & Regular & 12,9 & 11,7 & 12,3 \\
\hline & $\begin{array}{l}\text { Otros: Denigrante, vulgar, barato, comercial, ameno, incom- } \\
\text { petente, normal, serio, ameno, entretenido, grosero, popular, } \\
\text { premios, entretenido, juerguero, elocuente, huachafo, inven- } \\
\text { ta noticias, juerguero, poca información, controversial }\end{array}$ & 6,6 & 11,7 & 9,1 \\
\hline
\end{tabular}

El popular fue mayormente considerado de manera negativa, aunque lo más mencionado fue: bueno $(13,2 \%)$, además de un $16,6 \%$ que dice no lo lee. Mientras, los calificativos positivos fueron: Informativo, ameno, normal, serio, ameno, entretenido, elocuente. Siendo los varones los que, por ligera diferencia, opinan más negativamente que las mujeres. Entre los sectores poblacionales masculinos los calificativos más positivos, pero muy neutralmente ("informativo"), los obtuvo en Chorrillos y los más negativos en la Vivienda. Entre los sectores poblacionales femeninos, vemos que obtiene mejores calificativos en Pamplona y el Granda y los calificativos más negativos en Ventanilla.

Tabla N. ${ }^{\circ}$ 11. Porcentajes en términos para calificar al diario Ojo, según sexo en la población estudiada.

\begin{tabular}{lccc}
\hline \multicolumn{1}{c}{ Términos para calificar al diario } & \multicolumn{2}{c}{ Sexo } \\
& Femenino & Masculino & Total \\
\hline Chicha & 5,7 & 2,0 & 3,8 \\
Bueno & 14,4 & 13,0 & 13,7 \\
Variado & & 5,0 & 2,5 \\
Regular & 12,3 & 12,1 & 12,2 \\
Farandulero & 3,2 & 2,1 & 2,6 \\
Basura & 0,5 & 0,2 \\
Vulgar & 9,5 & 4,7 \\
$\quad \begin{array}{l}\text { No leo } \\
\text { Otros: elegante, malo, educativo, claro, rescatable, intermedio, } \\
\text { vulgar, serio, grosero, entretenido, popular, inventa noticias, } \\
\text { juerguero, poca información, ameno, huachafo, elocuente, } \\
\text { informativo, premios, controvertido, popular, neutral, amarillo, } \\
\text { poco creíble, variado, chevere, aburrido, innovador }\end{array}$ & 6,0 & 13,3 \\
\hline
\end{tabular}


En cambio, Ojo tiene mayormente calificativos positivos, siendo el más mencionado: bueno con $13,7 \%$ y regular $(12,2 \%)$, luego vienen los calificativos negativos: vulgar, chicha, farandulero, variado. Entre los sectores poblacionales masculinos, los calificativos más positivos los obtuvo en Chorrillos y los más negativos en La Agraria. Entre los sectores poblacionales femeninos, vemos que obtiene mejores calificativos en Pamplona y el Granda y los calificativos más negativos en Ventanilla y Callao.

Tabla N. ${ }^{\circ}$ 12. Porcentajes en términos para calificar al diario Extra, según sexo en la población estudiada.

\begin{tabular}{lccc}
\hline \multicolumn{1}{c}{ Términos para calificar al diario } & \multicolumn{2}{c}{ Sexo } \\
Mueno & Femenino & Masculino & Total \\
\hline Chicha & 13,2 & 8,5 & 10,8 \\
Basura/ malo & 1,3 & 2,9 & 2,1 \\
Regular & 3,2 & 9,5 & 12,7 \\
No leo & 18,1 & 12,9 & 15,5 \\
Extra & 13,7 & 23,7 & 18,7 \\
Vulgar & 9,5 & 6,0 & 7,7 \\
Serandulero & 3,2 & 1,6 \\
Basura & 2,7 & 1,4 \\
Otros: neutral, vulgar, piola, asco, serio, normal, divertido, & & 0,4 \\
erótico, sensacionalista, neutral, elegante, educativo, & 6,5 & 6,9 \\
educativo, importante, medio, informativo, porno & & 6.7 \\
\hline
\end{tabular}

Extra tuvo más calificativos positivos como: Regular, bueno; aunque, en menor medida, tuvo también calificativos negativos como: vulgar, asco, sensacionalista; y además un $18,7 \%$ de personas que no lo lee. Teniendo más calificativos positivos entre las mujeres. Entre los sectores poblacionales masculinos los calificativos más positivos los obtuvo en Chorrillos y Ventanilla y los más negativos en otro grupo de Chorrillos. Entre los sectores poblacionales femeninos, vemos que obtiene mejores calificativos en Pamplona y Chorrillos y los calificativos más negativos en otro grupo de Chorrillos.

Tabla 13. Porcentajes en términos para calificar al diario Perú 21, según sexo en la población estudiada.

\begin{tabular}{|c|c|c|c|c|}
\hline \multirow{2}{*}{\multicolumn{2}{|c|}{ Términos para calificar al diario }} & \multicolumn{3}{|c|}{ Sexo } \\
\hline & & Femenino & Masculino & Total \\
\hline \multirow{8}{*}{ Perú 21} & No leo & 10,4 & 13,5 & 11,9 \\
\hline & Bueno & 28,0 & 21,7 & 24,8 \\
\hline & Regular & 9,3 & 8,2 & 8,7 \\
\hline & Informativo & 6,7 & 7,7 & 7,2 \\
\hline & Serio, positivo & 8,9 & 4,8 & 6,8 \\
\hline & Político & 4,7 & 1,8 & 3,2 \\
\hline & Excelente, muy bueno & & 3,1 & 1,6 \\
\hline & $\begin{array}{l}\text { Otros: habla de Perú, habla la verdad, asertivo, medio lo } \\
\text { mejor, medio, aburrido, }\end{array}$ & 5,3 & 4,8 & 5,0 \\
\hline
\end{tabular}


Finalmente, Perú 21 obtuvo las mayores calificativos, así Bueno llega a 24,8\%, y un $6,8 \%$ lo considera político. Son las mujeres las que tienen mejor opinión sobre ese diario. Además, es el diario que mayormente se le considera bueno, serio, positivo, siendo en general sobre el que habría mejor opinión, pero esto contrasta con un $12 \%$ que no lo lee. Entre los sectores poblacionales masculinos los calificativos más positivos lo obtuvo en La Agraria y Chorrillos y los más negativos en otro grupo de la Vivienda y Callao. Entre los sectores poblacionales femeninos vemos que obtiene mejores calificativos en Pamplona, Granda y La Agraria y los calificativos más negativos en Callao.

Tabla 14. Preferencia de diarios según instrumento aplicado.

\begin{tabular}{|c|c|c|}
\hline Observación participante & Grupo focal & Encuesta \\
\hline $\begin{array}{l}\text { En la mayoría de kioscos ob- } \\
\text { servados se encontró que el } \\
\text { diario Trome se encuentra en } \\
\text { el primer lugar de las pref- } \\
\text { erencias del público, argu- } \\
\text { mentado usualmente por el } \\
\text { "lenguaje usado", las "pro- } \\
\text { mociones", "la información } \\
\text { acerca de la realidad", etc. }\end{array}$ & $\begin{array}{l}\text { Las preferencias de } \\
\text { compra de estos dia- } \\
\text { rios es dispersa, el más } \\
\text { aceptado dentro de los } \\
\text { diarios chicha (como } \\
\text { ellos los llamaron) es } \\
\text { Trome. }\end{array}$ & $\begin{array}{l}\text { Dentro de lo investigado se } \\
\text { obtuvo que más del } 40 \% \\
\text { de las personas encuesta- } \\
\text { das señala que el diario } \\
\text { más leído es el Trome, el } \\
\text { segundo es El popular, } \\
\text { mucho más abajo se en- } \\
\text { cuentra El chino, obtenié- } \\
\text { ndose el mismo orden en } \\
\text { cuanto a su lectura. }\end{array}$ \\
\hline
\end{tabular}

Como vemos en el Cuadro 14, el diario "Trome", es el más preferido, llevando consigo el concepto del buen diario, concibiendo por los jóvenes como buen diario (según la encuesta realizada), a aquel que traiga consigo "cosas de la historia, fotografías", "hoja de experimentos y crianza de cuyes (grupos focales); sin embargo las secciones más leídas, son las de espectáculo, seguidas por las de deportes y luego por las de política, en un último lugar se encuentran las noticias de economía y las culturales; el deporte juega un papel importante para el sexo masculino y los espectáculos, en el femenino. Como vemos, las personas tienen el concepto de lo más adecuado en mente, sin embargo, sus preferencias están en lo más asequible hacia ellos.

\section{Preferencias en programas televisivos}

El programa televisivo más preferido es "Habacilar" de Raúl Romero con 10,2\%. El programa de Magaly es segundo con 7,1\% sin embargo es visto por la gran mayoría $(70,7 \%)$, pese a calificarlo con gran cantidad de calificativos negativos. Luego siguen: Cuarto Poder, Ventana Indiscreta, El especial del humor, noticieros, telenovelas, Así es la vida, Los Simpson. Luego hay una preferencia por una gran variedad de programas como: Películas, Friends, Buenos días Perú, MTV, BBC, 24, History Chanel, Roma, Charmed, Latin American, Pañorama, 24 horas, Perú surf, Cazadores de Mitos, Dragon, I love, 
Expedientes X, 3 Chiflados, Buena Tierra, Los inimitables, Next, Aventura culinaria, Oh Diosas, Lucha, Snack Down, Animal Planet, Alma Gemela, Primero a las 8. Otros: (cada uno) Warner Chanel, Cinescape, TNT, Sétimo Puesto, Recargados de risa, Decisiones, CSI, Confirmado, Disney, ATV, CNN, Confirmado, Show de goles, Pañorama, 36, Polizontes, MTV, Canal 26, Canal 74, Scarbs, Biografías, Utilísima, Fulaños y Mengaños, Cold Case, Ley y el Orden, Porque callamos las mujeres, National Geographic, Full House, Mónica, El Zorro, La fea más bella, Fox Sport, ESPN, Cinescape, Francotirador, La sarita, Pasión de gavilanes, De película, Sétimo Puesto, Canal N, El deportivo Decisiones, Chespirito. Dentro de los sectores poblacionales masculinos se prefiere Magaly sobre todo en Ventanilla con $7.7 \%$ y aquí Habacilar llega también primero con $20.6 \%$, Cuarto Poder es primero en la Vivienda, El Especial del Humor y Así es la vida en Chorrillos. Dentro de los sectores poblacionales femeninos se prefiere Magali, sobre todo, en Ventanilla con 29,2\% y aquí Habacilar llega también primero con 18,1\%, Cuarto Poder es primero en la Ruiz, El Especial del Humor en la Ruiz y las preferencias de programas son muy diversificadas entre ambos sexos según los programas especializados sobre documentales y series

La frecuencia con que ven Magaly es rara vez 44,7\% y varias veces a la semana $15,4 \%$, llegando los que lo ven todos los días a $10,6 \%$, siendo mayor el visionado entre las mujeres. Solo un $26,1 \%$ señala no ven nunca este programa. Dentro de los sectores poblacionales masculinos donde con mayor frecuencia la ven es en Ventanilla y el Callao y con menor frecuencia en la Ruiz y La Agraria. Dentro de los sectores poblacionales femeninos donde con mayor frecuencia la ven es en Ventanilla y el Callao y con menor frecuencia en la Ruiz, La Agraria y Pamplona.

Las expresiones ante este programa, sobre todo, fueron: "chismosería" $(17,2 \%)$ y "entrometida" $(6,5 \%)$; y pese a que la mayoría dice que es "una chismosa que ataca a los artistas" $(64,9 \%)$, un alto porcentaje indica "dice las verdades a la gente" $(28,2 \%)$. Otras expresiones negativas fueron: Basura, Sin sentido tonto, estúpido, vulgar y mentirosa, en ese orden; dentro de las positivas: Chévere, locazo, excelente, piola, bueno, y dice la verdad, periodista, normal, no es hipócrita. Otros términos referidos a ella fueron: espectáculo, bruja, figureti, a veces se pasa, exagerada, da información sin verificar, malo, habladora, incentivo mostrado por diarios, basura divertida, mala, controversial, chistoso, divertido, urraca, porquería, soplona, difama, discrimina, que se muera, poco informativa, regular, no debería ser así, oportunista, malicioso, convenida, asco, aburrido, creíble, pantalla, gana con problemas, populista, agresor, burla, desenmascara, preparada, fomenta machismo, moralizador, candelero, cínica, usurera, perjudicial, farandulera, mediocre, despreciable, propagandista, destructivo, deplorable, negocio, inculta, sensacionalista, envidiosa, hace quedar mal. Dentro de los sectores poblacionales masculinos donde la consideran mayormente chismosería es en Callao con $30 \%$ y Vivienda $20 \%$, que es entrometida en el Callao con $10 \%$, que dice la verdad en el Callao con $10 \%$, que es basura en la Vivienda con $17 \%$. Dentro de los sectores poblacionales femeninos donde la consideran mayormente chismosería es en Ventanilla con $40.6 \%$ y Pamplona 26\%, que es entrometida en el Granda con $17 \%$ y Callao con $14 \%$, que dice la verdad en el Granda con $9.5 \%$, que es basura en Ventanilla con $11 \%$ y la Ruiz $8 \%$. Será dentro de los sectores poblacionales no universitarios donde obtendrá los otros calificativos positivos. 
En general, las mujeres tienen mejor opinión que los varones sobre Magaly, ligeramente opinan en mayor medida que es una estrella de la TV, y un 37,8\% que dice las verdades, mientras que los varones en un $76,1 \%$ dicen es una chismosa que ataca a los artistas. Dentro de los sectores poblacionales masculinos donde más la consideran una estrella es en la Vivienda y en Chorrillos, que dice las verdades en el Callao y que es chismosa y ataca artistas en la Vivienda, Chorrillos y la Ruiz. Dentro de los sectores poblacionales femeninos donde más la consideran una estrella es en Chorrillos y la Ruiz, que dice las verdades en el Callao y que es chismosa y ataca artistas en el Granda, Pamplona y Chorrillos.

\section{Actitudes y prejuicios detectados en los diarios}

Se indica que estos diarios dan a los negros calificativos negativos, mayormente "rateros" $(16,7 \%)$, opinando así mayormente los varones (20,6\%); luego siguen otros calificativos como: Discriminados, insultos, chapas, cochinos, sucios y otros como: brutos, babosadas, come gatos, zapatón mofa, inferiores, descuidados, negros, menospreciados, parranderos. Esto es ligeramente mayor en los varones; siendo el único calificativo positivo: igualdad. Entre los sectores poblacionales masculinos los calificativos más positivos lo obtuvo en el Granda (y donde menos los califican de rateros, cochinos u otros) y los más negativos en otro grupo de Ventanilla y Chorrillos. Entre los sectores poblacionales femeninos, vemos que se abstienen de calificativos negativos en Granda y Ventanilla considerándolos a la vez "discriminados" y los calificativos más negativos en Chorrillos y Ventanilla, donde mayormente se los considera discriminados es en el Callao llegando al $57 \%$.

Los cholos son sindicados mayormente como "ignorantes" $(14,3 \%)$, siendo más elevado en los varones $(27,8 \%)$; la mayoría de calificativos son negativos: Insultos, serraños, feos, sucios, cochinos, rateros, choros, delincuentes, dejados y otros como: bajado de la Puna, babosadas, vulgar, igualdad, racismo, borrachos, explotados, burla, timados, malos, racistas, violadores, despectivo, paisaños, marginados, cholos, llama, sonsos, siempre timados, tonto, bajado de la Puna; dentro de los positivos tenemos: se supera, pueblo, trabajadores. Entre los sectores poblacionales masculinos que se abstienen de calificarlos negativamente son el Callao y Granda a la vez que los consideran discriminados y los más negativos en Ventanilla y Chorrillos (ignorantes, sucios). Entre los sectores poblacionales femeninos, vemos que obtiene mejores calificativos en Callao y los calificativos más negativos en Ventanilla.

Mientras que de los blancos "hablan bien" $(12,4 \%)$, siendo mencionado sobre todo por las mujeres $(16,4 \%)$. Es importante resaltar cómo un $19.4 \%$ no contesta siendo ligeramente mayor el número de varones los que se abstiene. Es también de destacar que los términos más mencionados por las mujeres son: gringos $16,4 \%$, que son corruptos $17,3 \%$ y que son creídos pitucos en $12,6 \%$; mientras que en los varones lo más mencionado es superiores $8,7 \%$, buenos $5,7 \%$ y dominante, de plata $5,5 \%$. La interrogante es si en los varones no hay un mayor deseo de ser considerado blanco por las acepciones positivas que otorga y prefieren calificarlos bien, ya que esto contrasta con las mujeres que señalan un mayor rechazo. Otros términos mencionados en la población es que son vistos en su mayoría positivos: lo máximo, los mejores, no se les puede tocar, babosadas, elite, enaltecen alta sociedad, tienen poder, preferidos, igualdad, limeños, ejemplo, profesionales, saben 
más, tienen futuro, amigos, gente bien, dueño de todo, políticos; y señalan algunos términos negativos como: borrachos, tramposos, ociosos, borrachos, infieles, gustan del placer, racistas, mentiroso, fresitas, mofa, sonsos, gringos, negativo. Entre los sectores poblacionales masculinos que se abstienen de calificarlos negativamente está la Vivienda a la vez que señalan los consideran positivamente y los más negativos en Ventanilla (creídos) y en la Agraria (corruptos). Entre los sectores poblacionales femeninos, vemos que obtiene mejores calificativos en Ventanillla y los calificativos más negativos en el Granda y Chorrillos, donde más se abstienen es en la Agraria donde llegan al $70 \%$.

Ante los términos negros, cholos y blanco, algunos prefieren abstenerse y no contestan llegando al 19,4\% ante los blancos y a 18,2\% ante los negros, siendo mayor en los varones al referirse a los negros llegando al 22,9\%; en el caso de los cholos llegó al 10,8\% siendo algo mayor entre los varones.

Los hombres son presentados negativamente mayormente como "machistas" 15,6\% y "mujeriegos" $11,5 \%$, siendo las mujeres las que presentan mayores porcentajes negativos con $16,6 \%$ para machistas pero llegando a $14,5 \%$ para mujeriegos frente al $8 \%$ de los varones; es de resaltar que las mujeres también señalan numerosos calificativos negativos como: Delincuentes, ociosos, malos, violentos; mientras que los varones tienen al calificativo con mayor negatividad y frecuencia a: basura, perros que llega a 7,6\% . Otros calificativos mencionados fueron dentro de los negativos: asesinos, dominantes, no se, borrachos, violadores, sexo fuerte, abusivos, burla, mandan, cachudos, salvajes, sensacionalismo, manipuladores; y dentro de los calificativos positivos: salvadores, lo máximo, trabajadores, buenos, más fuertes. Entre los sectores poblacionales masculinos que se abstienen de calificarlos negativamente está La Agraria (llega al 56,6\%) a la vez que señalan los consideran positivamente y los más negativos en Chorrillos, Ventanilla y Callao. Entre los sectores poblacionales femeninos, vemos que obtiene mejores calificativos en Pamplona y los calificativos más negativos en Ventanilla y la Agraria.

Las mujeres según la población son considerados por los diarios como "jugadorazas" con $13,7 \%$ aunque mostrando significativa diferencia pues en los varones llega a 20,9\% frente al $6,6 \%$ de las damas; a la vez que se menciona casi en igual proporción a "víctimas de abusos" que llega al 9,5\%; se menciona también trabajadoras, y otros términos más negativos como: sexo débil, inmorales, prostitutas, cachudas sobre todo por los varones. Otros términos además mencionados fueron: manipuladoras, tontas, lloronas, luchadoras, mal vivir, lindas, vividoras, fáciles, desprestigio, machistas, violadas, erotismo, instrumento, menosprecio, burla, buenas, pisadas, sarcasmo, objeto sexual, hembrita, mujeronas, perdición, liberales, sensacionalistas, fuente de placer, hablan mal, hermosas, basura, inferiores, degradan, inmaduras, sinvergüenzas, chismosas. Entre los sectores poblacionales masculinos que se abstienen de calificarlos negativamente está La Agraria y Callao a la vez que señalan los consideran positivamente y los más negativos en la Vivienda y en Chorrillos. Entre los sectores poblacionales femeninos, vemos que las consideran víctimas de abusos, sobre todo, en Callao y los calificativos más negativos en Ventanilla y el Granda.

Los homosexuales como vistos como "discriminados" entre ambos sexos llegando al $20,3 \%$ y a la vez que un sector dice "son lo peor" $7,8 \%$. Otros términos negativos fueron: mala influencia, exhibicionistas, mal social, mencionados por los varones y negativo 
mencionado por las mujeres. Otros términos fueron: pobres, cabros, asco, cosa de otro mundo, gente de mal vivir, escandalosos, basura, burlas, sensacionalistas, maricas, punto, perniciosos, desprecio, que mueran, gente de mal vivir, cabros, mal visto, farándula, mal social, raro, criticados, despreciados, hablan mal, se prostituyen, cochinos, fobia, repudio; y algo normal, racismo, a respetar. Entre los sectores poblacionales masculinos que se abstienen de calificarlos negativamente está la Agraria y Callao y los más negativos en la Ruiz y en Callao. Entre los sectores poblacionales femeninos, vemos que los consideran discriminados sobre todo en Callao y los calificativos más negativos se dan en el Granda y Ventanilla

Las vedettes son tipificadas negativamente incluyendo, sobre todo, "prostitutas" que llega a al 12,4\% y "tontas, calabazas, huecas, mujer sin cerebro" con $9.9 \%$ e indican en su gran mayoría no preferir a ninguna llegando al 54,9\% siendo mayor el porcentaje en las mujeres, y la única vedette que fue algo mencionada fue: Tula Rodríguez con 7,4\% llegando a 1,4\% en los varones y luego Mariela Zanetti con 4\%, es de resaltar un 13,2\% que no contesta.

Otros términos negativos sobre las vedettes que son mencionados mayormente por los varones son: exhibicionistas, vulgar, mal vivir, inmorales. Dentro de las mujeres fue mencionado jugadoras, regalonas con 10,3\%. Otros términos mencionados por los varones fueron: ricas, atractivas, buenasas con 7,9\%. Algunos términos positivos fueron: se ganan la vida así, es un trabajo saño o uno neutro como bailarina. También mencionados otros numerosos términos como: escandalosas sufrida, fáciles, bitch, deshonestas, sin futuro, malas para la sociedad, figuretis, desgracia, obscenidad, antimodelo, artista, una imagen sexual, provocadoras, mal usan siliconas, fuente de placer, vividoras, malcriadas, baja autoestima, feas, decentes, portada, sinvergüenzas, yucas, bataclanas, desvergonzadas, mal por que usan siliconas, incitan morbosidad, sexis, ridículo, anticultura, perras, desubicadas, distracción, deshonestas, sin futuro, sin sentido, controvertidas, bonitas, trabajadoras, no deben existir, mediocres, atrevidas, personas, soñadoras, ilusas, polillas, aprovechadoras, denigrante, extrovertidas, inmaduras, quieren ser conocidas, no artistas simpáticas, normales, sin dignidad, provocativas, interesadas. Dentro de los sectores poblacionales particulares masculinos tenemos que los calificativos más positivos se dieron en un sector de la Ruiz y mayor abstención en el Granda, los calificativos más negativos se dieron en Chorrillos y luego en la Ruiz y la Vivienda y dentro de los sectores poblacionales femeninos tenemos que los calificativos más positivos se dieron en el Granda y la Ruiz y los más negativos en Ventanilla y el Callao.

Sobre los futbolistas tienen más una imagen negativa, sobre todo, como "jugadorazos y mujeriegos" con $14,4 \%$ llegando las mujeres al $21,7 \%$ frente a un 7,2\% de los varones. Dicen también "perdedores" 3,3\% y "poco instruidos" 2,8\%; otros términos fueron borrachos que llega en los varones al 10,2\% que también los califican de conformistas $9,8 \%$ y creídos y vanidosos $6,6 \%$; otros términos referidos fueron: irresponsables, malos, púdranse, no juegan, incompetentes, entretenido, finteros, botados, dinero fácil, indisciplinados, narcisismo, desapasionados, impotentes, tontos, malogrados, faranduleros, papacitos, cueros, faranduleros, viciosos y solo fue mencionado dos términos positivos: triunfadores y rápidos. E indican en su gran mayoría no preferir a ninguno llegando al $26,1 \%$, siendo ligeramente mayor el porcentaje en las mujeres. Es también sintomático 
un $18,1 \%$ que no contesta que llega al $28,5 \%$ entre los varones y 7,8\% en las mujeres. Solo es algo mencionado Pizarro con 6,5\% mayormente por las mujeres que llega a 8,4\% frente al 4,7\% de varones. Luego, minoritariamente, son mencionados entre los peruaños: Farfán, Guerrero y Manco, luego siguen extranjeros como: Ronaldo y Ronaldihno. Otros mencionados fueron: Kaká, Zidane, Beckham, Acasiete, Ibáñez,Tutti, Cencho, Waldir, Delgado, Messi, Lolo, Mendoza, Montaño, Rebosio, Solaño, Butrón, Ciurliza, Mariño, Solaño, Merino, Palacios. Al interior de los sectores poblacionales masculinos, encontramos que los que otorgan mejores calificativos son el Granda a la vez que otro grupo del mismo se abstiene de calificarlos, luego un sector de la Ruiz trata de tomar una actitud neutra ("son deportistas") y los que los califican más negativamente son Chorrillos y Ventanilla. $\mathrm{Al}$ interior de los sectores poblacionales femeninos, encontramos que los que toman una posición neutra ("deportistas") son el Granda y Ventanilla y los que los califican más negativamente son Pamplona y otro sector del Granda.

Resaltan que en estos diarios se presenta violencia contra la mujer entre ambos sexos llegando al 88,4\%. Dentro de los grupos poblacionales masculinos los de mayor contestación afirmativa fueron Ventanilla con $93 \%$ y Chorrillos con 92\%, los que contestaron más negativamente fueron el Callao y la Vivienda, los que se abstuvieron fueron los de la Ruiz. Dentro de los grupos poblacionales femeninos, los de mayor contestación afirmativa fueron la Ruiz con $100 \%$ y Pamplona con $97 \%$, los que contestaron más negativamente fueron el Callao y Chorrillos, los que más se abstuvieron fueron los de Callao.

Indican que los contenidos de estos diarios son mayormente "malintencionados" con $49,3 \%$ siendo algo mayor entre los varones con $54,4 \%$, mientras que un $18,5 \%$ dice son neutrales y $17,7 \%$ que se preocupan por los problemas sociales llegando entre las mujeres a $22,7 \%$; en general, la percepción de las mujeres es mejor que la de los varones frente a los contenidos de estos diarios. Dentro de los grupos poblacionales masculinos donde mayormente opinan que se preocupan por los problemas sociales es en Callao y Chorrillos; donde más opinan que son malintencionados es en la Vivienda y en La Agraria. Dentro de los grupos poblacionales femeninos donde mayormente opinan que se preocupan por los problemas sociales es, al igual que en los varones, en Callao y Chorrillos; donde más opinan son malintencionados es en La Agraria y en Pamplona.

Dicen que el lenguaje que usan estos diarios es mayormente "jerga" con 43,6\%, siendo algo mayor entre los varones, y "vulgar" que llega a 30,4\% algo mayor entre las mujeres y luego, viene "popular" con 18,3\% y "normal" con 8,2\%. Dentro de los sectores poblacionales masculinos donde mayormente opinan se usa jerga es en Ventanilla, luego la Ruiz y La Agraria, donde consideran el lenguaje es popular es mayormente en la Ruiz, luego en la Vivienda y Agraria; consideran el lenguaje como vulgar más en la Vivienda, luego en Chorrillos y en Ventanilla. Dentro de los sectores poblacionales femeninos donde mayormente opinan se usa jerga es en Pamplona, luego la Agraria, donde consideran el lenguaje es popular es mayormente en la Ruiz, luego en Callao y Agraria; consideran el lenguaje como vulgar más en Ventanilla (casi 60\%), luego en Pamplona.

Creen que estos diarios no usan su mismo lenguaje con un 73,8\% llegando entre las mujeres a $83,4 \%$, pero un alto porcentaje indica que sí tienen el mismo lenguaje $23,4 \%$ en total y siendo superior entre los varones que llega al $32 \%$. Entre los grupos poblacionales 
masculinos creen que no usan su mismo lenguaje es en la Ruiz y luego la Vivienda, con altos porcentajes en todos los grupos; sí consideran tienen su mismo lenguaje sobre todo en Callao con $60 \%$ y Chorrillos con $40,4 \%$. Entre los grupos poblacionales femeninos creen que no usan su mismo lenguaje es en la Ruiz (100\%) y luego Chorrillos, con altos porcentajes en todos los grupos; sí consideran tienen su mismo lenguaje sobre todo en Ventanilla con $33 \%$ y el Granda con $22 \%$

Sin embargo, la mayoría muestra confundir la jerga que utilizan estos diarios, así al interpretar expresiones como: "Chotean milicos que jamaron con Mantilla", "Se le para el bobo en pleno chuculún", "Chibolo mete punta en caja a teclito"; siendo mayor el problema frente a esta tercera expresión pues si bien presenta menor porcentaje que señala no entiende $49,8 \%$ frente al 51,6\% de la primera expresión, al momento de señalar lo que significa equivocan dando lugar a diversas frases que equivocan lo que significa "caja" que lo asocian a cajero, banco, caja fuerte, abdomen, abdomen, cabeza; o que simplemente se aproximan como: joven apuñala a viejito (anciaño) 10,7 \% Adolescente acuchilla a otro 6,7\%, solo un $6,7 \%$ interpretó correctamente esta frase: mientras la primera frase es interpretada correctamente por $9,5 \%$ y otra con una aproximación que llega al $8 \%$. Tampoco frente a la segunda frase hay buena interpretación pues aunque llegan a comprenderla un 49,8\%, un 2,3\% no la entendió y algunos mencionaron expresiones como: se erectó, en pleno baile se le para el corazón, se detiene el corazón, se emociona bailando, pasó algo malo. En general, las mujeres tuvieron mayores problemas al leer estas expresiones, señalando no comprenderlas en un $60,3 \%$ frente a la primera expresión, 54,4\% frente a la tercera, y $26,6 \%$ frente a la segunda; frente a un problema en los varones en un $42,9 \%$ frente a la primera, $33,6 \%$ frente a la tercera y un $18 \%$ frente a la segunda expresión.

Dentro de los grupos poblacionales masculinos, los que más entienden estas expresiones son los de la Vivienda respecto a las 2 primeras y en Ventanilla frente a la tercera expresión. Los que mostraron mayor dificultad fueron los de La Agraria y la Ruiz para interpretar las 3 expresiones. Dentro de los grupos poblacionales femeninos, los que más entienden estas expresiones son los de Ventanilla frente a las tres expresiones. Los que mostraron mayor dificultad fueron los de Pamplona y Callao para interpretar las 3 expresiones, la Ruiz y La Agraria también mostraron dificultad, pero en menor medida.

Respecto a expresiones como "los cholos son ignorantes" en su mayoría están en desacuerdo (70,6\%), sobre si "los negros son mejores futbolistas" la mayoría también está en desacuerdo $(62,8 \%)$ similar entre ambos sexos; pero un regular porcentaje dice estar de acuerdo $(22,1 \%)$. Igualmente están en desacuerdo con "las charapitas son mujeres fáciles" $(55,9 \%)$ y "las vedettes son prostitutas" $(48,1 \%)$, pero sobre estas dos últimas expresiones hay mayor porcentaje de personas de acuerdo, lo cual revela fuertes prejuicios y temores frente a este tipo de personas, así frente a las "charapitas" un $28 \%$ está de acuerdo en que son mujeres fáciles y frente a si las vedettes son prostitutas un $37,4 \%$ estuvo de acuerdo. Es sintomático también que más de un $20 \%$ frente a estas dos expresiones no conteste. Las mujeres están ligeramente más de acuerdo que los varones en su actitud negativa ante las charapitas, y los varones respecto también ligeramente al denominar prostitutas a las vedettes. Es importante también señalar que un $21,7 \%$ entre los varones no contestó frente a si los "cholos son ignorantes" y un 21,2\% frente a si "los negros son mejores futbolistas". 
Dentro de los sectores poblacionales masculinos, vemos que donde hay mayor acuerdo sobre si "Los negros son mejores futbolistas" es en el Callao y mayor desacuerdo en la Ruiz y San Martín. Sobre si "Las charapitas son mujeres fáciles" mayor acuerdo en el Callao y mayor desacuerdo en la Ruiz y San Martín. Sobre si "Las vedettes son prostitutas" mayor acuerdo en Callao y mayor desacuerdo en la Ruiz y San Martín. Sobre si "Los cholos son ignorantes" mayor acuerdo en la Vivienda que a su vez tiene mayor abstención y mayor desacuerdo en el Callao y en San Martin. Dentro de los sectores poblacionales femeninos, vemos que donde hay mayor acuerdo sobre si "Los negros son mejores futbolistas" es en el Callao y La Agraria y mayor desacuerdo en la Ruiz y San Martín. Sobre si "Las charapitas son mujeres fáciles" mayor acuerdo en el Callao y La Agraria y mayor desacuerdo en la Ruiz y San Martín. Sobre si "Las vedettes son prostitutas" mayor acuerdo en Callao y La Agraria y mayor desacuerdo en la Ruiz y San Martín. Sobre si "Los cholos son ignorantes" mayor acuerdo en la Vivienda que a su vez tiene mayor abstención y La Agraria y mayor desacuerdo en el Callao y en San Martín.

Lo positivo que señalan, según estos jóvenes, estos diarios es la entrega de regalos con un $32,9 \%$, similar entre ambos sexos, y traen láminas $(31,5 \%)$, un 15,4\% dicen dan "oportunidades de trabajo" y un $8,8 \%$ que dan consejería psicológica. En el sector masculino donde más se valora los regalos y sorteos es en el Callao y el Granda, las láminas educativas en Ventanilla, informes de salud en la Ruiz y Chorrillos, oportunidades de trabajo en Chorrillos y Ventanilla; la consejería psicológica es más valorada en Ventanilla. En el sector femenino donde más se valora los regalos y sorteos es en Ventanilla, las láminas educativas en Ventanilla y Callao, informes de salud en Ventanilla, Chorrillos y la Ruiz, oportunidades de trabajo en Chorrillos y Ventanilla; la consejería psicológica es más valorada en Ventanilla.

El público joven mantiene una actitud ambivalente frente al discurso de la prensa sensacionalista, pues si bien censura el tratamiento de diversos problemas y alaba la seriedad de otra prensa considerándola seria, no consume esta prensa supuestamente alternativa, además que se muestra muy conocedor de "estrellas" promocionadas (como vedettes, futbolistas y otros) y de sus vidas privadas, vive canalizando en muchos casos sus deseos en ellos, con mecanismos de proyección e identificación, afirmando actitudes constructivas o destructivas. Es así que detrás del discurso cotidiaño del público encontramos condensaciones (que reúnen en una sola historia: datos objetivos, rumores, fantasías de diversas historias para explicar un historia específica); es allí donde esta prensa alimenta estas condensaciones.

Los procesos de cambio que ocurren en la persona no son desencadenados tan solo por la prensa sensacionalista, sino que tras ellos existen diversas variables que influyen en la persona, desde que se genera la realidad mediática, hasta que es procesado por la persona, en uno y en otro medio, creyendo ilusamente en la variedad existente en los medios de comunicación, cuando muchos son uno mismo. De este modo esta prensa forma (o deforma) a las personas, y del mismo modo las personas le corresponden formándola. Esta estructura dinámica se sigue manteniendo y corre el riesgo de perennizarse si no se hace algo al respecto. En este tipo de casos la dinámica tiene dos opciones: o ha de romperse o ha de transformarse por alguno de los dos lados. 
Existe un alto Consumo de portada (titulares) a diferencia del Consumo de Contenido (compra de diarios) sean sensacionalistas o no. Esta se da en una proporción de 4 a 1 en un $80 \%$ de los puestos de periódicos observados.

El consumo de diarios sensacionalistas responde a preferencias preconcebidas del público, que posiblemente han sido configuradas durante el transcurso de su vida, por medio de propaganda, referencia externa (familia, amigos, trabajo, etc.), o influencia de las mismas estrategias que usan los diarios para vender su producto (promociones, sorteos, ofertas, etc.).

Se halló que las preferencias hacia el consumo directo de los diarios se da más en las mujeres que en los varones, que por otro lado, se manifiestan más como Consumidores de portada, y específicamente los jóvenes menores de 30 años (hasta 111 personas en una hora de observación). De un $75 \%$ de kioscos observados se encontró que el diario Trome se encuentra en el primer lugar de las preferencias del público.

Existe una confusión para diferenciar entre diarios "sensacionalistas" y "serios". Encontrándose que la importancia, éxito o seriedad de un diario, es entendida o medida en función de la demanda y la aceptación popular con la que cuenta. En las preferencias hacia el consumo se ha encontrado una jerarquía entre los diarios sensacionalistas en estudio. En primer lugar Trome, en segundo lugar El popular, en tercer lugar Ajá y en último lugar $\mathrm{El}$ chino.

La construcción de la identidad nacional ha girado relevando los acontecimientos suscitados en el ámbito deportivo (fútbol), mostrando además expectativas ante cada evento, logro o frustración del peruaño.

Se produce una "cotidianización de la violencia", agregándose a ello actitudes de fatalismo y pesimismo hacia la misma vida y el futuro.

Esta prensa sensacionalista vende evasión, desesperanza y falsa realización. Lejos de ofrecer objetividad para analizar la realidad, se ofrece evasión, formas prejuiciosas y estereotipadas de ver la realidad. La visión de lo humaño, de las relaciones, del país, de los personajes, de las personas es sumamente pesimista. Se ofrece compensar la pobreza de habilidades sociales, la incomunicación, la baja autoestima existente en la población peruana con una falsa realización a través del seguimiento de la cotidianeidad de los personajes de la farándula. Igualmente, la pornografía no está asociada a lo sexual, pues lo que hay es un tratamiento de lo erótico en el sentido de consumo de imágenes y formación de un imaginario sobre los personajes de la farándula, tratando de "vedettizar" incluso a los personajes políticos, intelectuales, etc., y erotizar los diversos espacios públicos y privados, así lo pornográfico se extiende a la presentación morbosa de los accidentes, crímenes, maltratos, líos amorosos asociados a simbiosis destructivas.

\section{RESULTADOS MÁS RELEVANTES}

- Entender la prensa sensacionalista como reflejo de actitudes que se dan en nuestra población, que revelan un imaginario, representaciones sociales y atribuciones que se manejan en la cotidianidad. 
- Ver el sensacionalismo y lo chicha dentro de una acepción que refleja prácticas culturales diversas.

- Detrás del discurso sensacionalista hay una promoción del consumo y una formación del imaginario popular con estos fines consumistas.

- Un espacio de comunicación privilegiado es el rumor y el chisme, los cuales cumplen funciones sociales y constituyen una diversidad pues pueden tener un carácter constructivo o destructivo. Así pueden promocionar, acompañar en un duelo (frente a un abandono o pérdida) o promover determinadas habilidades; como pueden censurar comportamientos, sentimientos o difundir creencias.

- $\quad$ En un sector de esta prensa sensacionalista, muchas veces se acompaña violencia e incluso justificación de la violencia contra la mujer y el feminicidio (resaltando supuestos causales los cuales han facilitado le ocurriera una agresión a diversas mujeres que lo sufren sobre todo por parte de sus parejas.

\section{IMPACTO Y APORTE DEL ESTUDIO}

Desde la Psicología, se ha develado que la prensa sensacionalista engarza con una cotidianidad que da sustento a una identidad en construcción que tiene aspectos limitantes y promotores de desarrollo, que se relacionan con motivaciones de afiliación y de logro, donde la autoestima y asertividad se alimentan de logros, reconocimientos, esperanza o desesperanza. Se incentiva una lógica donde para lograr posicionamiento de planteamientos o alternativas o reconocimiento a personas se pasa por una lógica de sistema de estrellas donde los diversos espacios (deportivo, político, científico, etc.) se vuelve espectáculo y en muchos casos se vedetiza. Este discurso nos revela un conjunto de necesidades sociales y motivaciones existentes en la población, que a veces son intuidas por el poder de turno y manipuladas con fines autoritarios; esta prensa se constituye en un canal para la exploración de personas.

\section{CONCLUSIONES}

- $\quad$ El tema sexual es privilegiado en estos medios, pero no como lo pornográfico o lo erótico, sino como instrumento de consumo, intentando convertir en espectáculo lo cotidiaño y los diversos espacios sociales y discursos.

- Esta prensa intenta canalizar deseos, necesidades y motivaciones de los sectores juveniles que muestra una complejidad a ser profundizada.

- $\quad$ Los contenidos de esta prensa muestran violencia contra la mujer, lo cual es percibido por un muy alto porcentaje del público; sin embargo en algunos casos esta prensa no cuestiona esta violencia antes bien presenta supuestos causales que generaron esta violencia incluyendo el feminicidio.

- Esta prensa canaliza un tipo de comunicación prejuiciosa y a través de emociones inauténticas lo cual revela problemas de habilidades sociales como baja autoestima 
y poca asertividad, pero sobre todo problemas de motivación de logro y toma de decisiones.

- $\quad$ El lenguaje utilizado por esta prensa es considerado vulgar y jerga por los jóvenes, e incluso un porcentaje de ellos considera que utiliza su mismo lenguaje; sin embargo, mucha de esta jerga no es comprendida o es interpretada de diferente forma, lo cual puede indicar afán de estar de moda y en otros casos no comprometerse con ella.

- A través de esta prensa se proyectan una serie de sentimientos y actitudes, las cuales muestran en muchos casos la existencia de una disonancia cognoscitiva entre creencias, conocimientos y comportamientos.

- Hay un alto conocimiento de las historias del mundo del espectáculo entre los jóvenes pese a que se censura este tratamiento en la prensa, pero el consumo de este discurso y personajes es alto, e incluso se da una identificación con personajes promocionados por esta prensa como vedettes y futbolistas, como un sistema de estrellas a través de los cuales un buen sector de la población busca realización pese a que son severamente criticados o calificados incluso considerando a los futbolistas como fracasados, y esto último se liga a problemas de construcción de identidad nacional. Un conjunto de temores están detrás de la censura a personajes como las vedettes y charapas en un sector de la población. Este alto consumo lleva a promover que otros personajes políticos o profesionales entren al mismo, a la vez que estos personajes buscan ingresar a esta lógica como forma de acceder al reconocimiento del público consumidor de medios.

- La realidad es manipulada a diversos niveles en el discurso de esta prensa, pero los consumidores en alto porcentaje se comprometen con esta manipulación y plantean demandas para que esta prensa se pronuncie para aliviar temores, fantasmas, deseos y búsqueda de alternativas a sus diversas problemáticas.

\section{AGRADECIMIENTOS}

Se agradece especialmente al Mg. Marcel Velásquez, Coordinador de la investigación interdisciplinaria, y a los alumnos de Psicología: Eli Malvaceda, Melissa Cueva, Israel Rivera, John Espinoza y Alan Vega.

\section{REFERENCIAS BIBLIOGRÁFICAS}

1. Blanco, D. (1980). Metodología del análisis semiótico. Lima: Universidad de Lima.

2. Blanco, D. (1982). Imaginario Popular. Lima: Universidad Nacional Mayor de San Marcos.

3. Blanco, D. (1986). Comunicación y sociedad. Lima: Scientia y praxis.

4. Castilla Del Pino, C. (1978). Obras Completas. España: Alianza Editorial.

5. Castoriadis, C. (1975). La institución imaginaria de la sociedad. Buenos Aires: Tusquest. 
6. Doelker, H. (1978). La realidad manipulada. Barcelona: G. Gili.

7. Froom, E. (1964). Psicoanálisis de la sociedad contemporánea. México: Fondo de Cultura Económica.

8. García, Carmen (1999). Comunicación Interpersonal. Chile, Alfaomega.

9. Hevia, J. (2008). Habla jugador, jages y oficios de la jerga peruana. Lima: Taurus.

10. Lacan, Jacques (1980). Escritos. París

11. La Rosa, A. (2008). La gente y su aparato. Historias testimoniales sobre el uso de celulares. Lima: Ediciones del autor

12. Mattelart, A. (1981). Comunicación y nueva hegemonía. Lima: CEDEE \& CELADEC.

13. Martín-Baró, I. (1989). Los medios de comunicación masiva y la opinión pública en El Salvador 1979-1989. XV Congreso Internacional de la Asociación de Estudios Latinoamericaños.

14. Mc. Connell (1978). Psicología. México: Interamericana.

15. Merani, Alberto (1973). Psicología y alineación. México: Grijalbo,

16. Morales y otros (1994). Psicología. Social. Madrid: Mc Graw Hill.

17. Montero Maritza (1984). Ideología, Alineación e Identidad Nacional Caracas: EBUC.

18. Montero, Maritza (1990). Psicología de la Liberación, propuesta para una teoría psicosociológica. Conferencia en la Universidad de Hamburgo, junio.

19. Montero, Maritza y otros (1994). Construcción y crítica de la psicología social. Barcelona: Ed. Anthropos U.C.V.

20. Ortiz Pedro (2003). Formación de la personalidad. Lima: Orión.

21. Rodríguez Freddy (2005). Categorías de representación social en canciones de la sierra peruana alusivas al consumo de alcohol y subavaloración personal. Lima: Universidad Nacional Mayor de San Marcos.

22. Silva Santisteban, R. (2008). El factor asco: Basurización simbólica y discursos autoritarios en el Perú contemporáneo. Lima. Red para el Desarrollo de las Ciencias Sociales en Perú.

23. Suárez, Luis (2004). Género y Technocumbia: Subversión de las bellas. Lima: Universidad Nacional Mayor de San Marcos.

24. Tarrioni, E. (1975). Comunicación de masas, perspectivas y métodos. Barcelona G. Gili.

25. Yaroschevsky, M. (1983). La psicología del siglo XX. La Habana: Ed. Pueblo Educación.

26. Watzlawick, P. (1974). Teoría de la Comunicación Humana. Buenos Aires: T. Contemporáneo. 